\title{
L2 Listening Expertise: A Deliberate Practice Approach
}

\author{
Nasrin S. Altuwairesh, PhD \\ King Saud University, Saudi Arabia
}

Received: July 20, $2021 \quad$ Accepted: August 8, $2021 \quad$ Published: August 9, 2021
doi:10.5296/ijele.v9i2.18918ＵRL: https://doi.org/10.5296/ijele.v9i2.18918

\begin{abstract}
About
Nasrin Altuwairesh is Assistant Professor of TESOL at the College of Languages and Translation at King Saud University in Riyadh, Saudi Arabia. She holds a PhD in Education/TESOL from the University of Leeds in the United Kingdom. Her research interests focus on language learning and teaching, teaching EFL listening in particular.
\end{abstract}

ORCID id/ https://orcid.org/0000-0003-0823-0743

\begin{abstract}
The significant role listening plays in second language acquisition is now well-established. However, despite changes in the perception of second language (L2) listening, it remains an under-researched skill. Listening is the most challenging of the four language skills in terms of both learning and teaching. This calls for more research to tackle issues with the teaching and learning of L2 listening. Expertise is thought to be the end result of engaging in extensive amounts of deliberate practice. However, metacognitive instruction and deliberate practice done separately are rarely enough to achieve L2 listening expertise. Thus, this article proposes a new approach to L2 listening, in which metacognitive instruction is an essential element, but not an end in itself. This new approach to L2 listening integrates both metacognitive instruction and deliberate practice to gain benefits and overcome the shortcomings in the two approaches. Therefore, the combining of metacognitive instruction with deliberate practice challenges the current approach to teaching L2 listening.
\end{abstract}

Keywords: L2 listening, metacognition, metacognitive strategies, metacognitive awareness listening questionnaire (MALQ), listening expertise, deliberate practice 


\section{Introduction}

The commonly held views and the approach to L2 Listening are changing (Vandergrift, 2004). Once labelled the 'Cinderella of language skills' (Nunan, 2002), the primacy of listening in L2 learning is now well-established (Field, 2002, Vandergrift, 2007). The status of listening comprehension in language learning and teaching was "one of neglect" up to the end of the 1960s (Lynch, 2006). This consequently had a negative effect on the way listening was viewed and the role it played in language learning. The common assumption was that both language learners and teachers "know how" to listen in their native language and, hence, L2 listening will "develop on its own" (Feyten, 1991, p. 175).

It was only during the time of communicative language teaching (CLT) that listening finally gained its "rightful place" in the language classroom (Vandergrift and Goh, 2009). It was then that applied linguists started to realize the significant role listening plays in facilitating access to the L2, and that it was listening, rather than any of the other language skills, which served as the trigger for language acquisition (Rost, 2001). Previously viewed as a passive skill, listening is now seen as an active and highly integrative skill; a skill through which the rules of a language are internalized and other language skills emerge (Vandergrift, 1997).

Although developing L2 listening is crucial, a listening lesson seldom teaches language learners how to listen effectively (Vandergrift, 2007). The comprehension approach, being the norm in most L2 classrooms across the globe, tends to test rather than actually teach listening. Focusing on the product rather than the process of L2 listening is in fact a form of testing rather than actually teaching learners how to go about a listening text (Mendelsohn, 2006). However, the interest of listening instruction has recently been directed towards raising the learners' awareness of the process of listening (Vandergrift, 2004). Field (2008a) states that a significant amount of evidence from brain imaging indicating that a vast number of interrelated processes support listening already exists, and that the areas responsible for these processes are widely distributed throughout the brain. This means that a sub-skills approach to teaching listening is not a very effective one. This would also be an argument for deliberate practice where the focus is on practicing the skill in general, rather than dividing it up into component skills. The term deliberate practice has been in fact mentioned in the area of second language acquisition (Ortega, 2009), yet few if any attempts have been made to take this a step further by applying it to the language classroom. Therefore, this article sheds some light on the elements which are necessary for effective L2 listening practice in the classroom. The article attempts to review current approaches to teaching L2 listening and add to the existing body of knowledge by proposing the deliberate practice approach to L2 listening.

\section{L2 Listening: Theoretical Background}

While listening, learners process incoming speech under severe time pressures, hence processing that requires less attentional resources becomes an advantage (Vandergrift \& Goh, 2009). This is known as automatic processing. Being able to process information automatically is a desired goal in language learning, since automaticity is believed to reduce 
the cognitive load placed on learners. The skill acquisition theory, which relates to the development of expertise in any skill, best explains how automaticity is achieved. In fact, Bereiter and Scardamalia (1993) believe that Anderson's skill acquisition theory "links up nicely to ideas about expertise" (p. 89).

Anderson (2010), having examined the nature of expertise in a variety of fields, believes that it has influenced the understanding of the mechanisms underlying skill acquisition. Both brain imaging and behavioral studies confirm that the way a skill is carried out can change with practice (Anderson, 2010). The skill acquisition theory is one specific type of information processing theory which explains "L2 learning as the process of gradual transformation of performance from controlled to automatic" (Ortega, 2009, p. 106). According to DeKeyser (2007b), this theory explains the way people progress, from novice levels to proficiency, in a variety of skills including cognitive and psychometric ones.

Anderson (2010) argues that the development of any skill consists of three stages: cognitive, associative and autonomous. The first stage, i.e., the cognitive stage, is when learners "commit to memory a set of facts relevant to the skill," and they typically rehearse the facts when they perform the skill for the first time (p. 2). The use of knowledge at this stage is very slow due to it still being in declarative form. The second stage is the associative stage in which errors in the initial understanding are first gradually noticed and dealt with. Then, the connections that link the different elements needed to successfully perform the task become stronger, thus paving the way for a successful performance of the skill. The final stage is the autonomous stage in which, according to Anderson, procedures become gradually more rapid and automated.

One characteristic most commonly associated with automaticity is fast processing. Consistent practice and massive amounts of repetition are required to promote automaticity (Segalowitz, 2003). Fast processing is particularly desirable in the case of L2 listening due to listening being online and ephemeral in nature. For L2 listeners to be able to process the input faster, declarative knowledge of the target language, especially phonological knowledge, must be automatized (Goh, 2005). Research indicates that the comprehension of L2 learners suffers "as a result of the inability to automatize word recognition skills" (Goh, 2005, p. 66). Although automaticity frees mental resources to a great extent, it is achieved at the cost of loss of conscious access. As a result, a learner can no longer introduce changes easily to a well-practiced procedure (Bereiter \& Scardamalia, 1993). The deliberate practice approach demonstrates how the negative impact of automaticity might be dealt with.

\subsection{L2 Listening Expertise}

The concept of 'expertise' has been around since the beginning of civilization, but its nature and development was not studied and looked into until recent times (Bereiter \& Scardamalia, 1993). In fact, an extensive amount of research has been conducted over the last four decades with the purpose of examining the nature of expertise in a variety of fields, including chess, music, computer programming and mathematics (Anderson, 2010). The term 'expertise' is defined by Ericsson (2006a) as "the characteristics, skills, and knowledge that distinguish experts from novices and less experienced people" (p. 3). 
In the sphere of language learning, it is essential to achieve high levels of listening due to the fact that this particular skill is key to acquiring other language skills. In fact, any "significant development in an L2 requires a great quantity of listening" (Rost, 2006, p. 49). Further, listening competence has a critical impact on language learners' motivation (Field, 2008a). L2 listening expertise, a term coined by Goh (2005), is developed in part by the growth of systemic knowledge of the L2, including phonology, syntax, semantics, as well as pragmatic and discourse knowledge. This declarative knowledge needs to be proceduralized or automatized for effective language use to happen. Yet, declarative knowledge on its own is not enough to arrive at L2 listening expertise (Goh, 2005). She adds that besides linguistic knowledge, the development of L2 listening expertise requires metacognitive knowledge, strategies, and control. Control, according to Goh, includes both knowledge and strategies that enable the L2 listener to process the listening input more effectively. Expertise includes "not just what is known, but knowing when and how to use what is known" (Goh, 2005, p. 14), the latter being achieved through experience and training.

Anderson (2010) states that research involving brain imaging demonstrates that more efficient mental execution is reached through more practice. Extensive practice, Anderson believes, can facilitate the development of "the high levels of expertise in novel domains that have supported the evolution of human civilization" (p.281). The study of a foreign/second language is no exception. However, Ericsson (2006b) explains that an extensive amount of experience in one domain does not inevitably lead to an expert level of attainment.

Practice in the field of L2 learning actually entails "remains remarkably unexamined from a theoretical point of view," and has seldom been addressed directly in the post-audio-lingual time (DeKeyser, 2007a, p. 1). Nonetheless, in the sphere of SLA, DeKeyser (2007a) defines the term practice as "specific activities in the second language, engaged in systematically, deliberately, with the goal of developing knowledge of and skills in the second language" ( $p$. 8). The focus of practice in the audio-lingual era was on structures, rather than the actual behavior of language learners. Drills at that time were practiced in a mechanical behavior repeatedly and deliberately with the aim of producing certain aspects of the second language. However, in order for automatization to develop, which would lead to a change in behavior, language learners should be required to practice the actual behavior, and not de-contextualized structures. The definition DeKeyser provides for practice seems to be quite similar to the way Ericsson, Krampe and Tesch-Römer (1993) define the term deliberate practice, which according to them is "activities that have been specially designed to improve the current level of performance" (p. 367). Yet, neither DeKeyser nor Goh mention the term deliberate practice in their works on practice in SLA and L2 listening expertise, respectively.

The term 'L2 listening expertise' itself, although coined by Goh in 2005, seems not to have been taken further and, to my knowledge, no studies to date have been conducted to investigate the concept. Thus, this article is an attempt to revive the concept of 'L2 listening expertise' and moreover add an essential element, i.e., deliberate practice, that has not been mentioned by Goh. Hence, I argue that in order to achieve expertise in L2 listening, deliberate practice along with metacognition are two crucial components. Before discussing the concepts of metacognition and deliberate practice, I will first shed light on the 
comprehension approach, due to its prevalence in most L2 listening classes around the world.

\subsection{The Comprehension Approach}

During the era of communicative language teaching (henceforth CLT), the perception of listening changed from something that can be easily "picked up", to a complex communicative skill that has to be taught similar to other language skills (Vandergrift \& Goh, 2012). CLT brought with it an emphasis on practicing core listening skills, such as listening for gist, listening for details, selective listening and inferencing (Vandergrift \& Goh, 2012). Another key development during the CLT era was the introduction of a pre-listening phase aimed at activating learners' schema knowledge (Goh, 2008). All of these elements form what is known today as the comprehension approach, which is the norm in most listening classes around the globe (Field, 2008b).

Despite the fact that learners are given more listening activities in classrooms today, they are still left on their own to find ways to develop their listening abilities, with minimal direct support from teachers (Vandergrift \& Goh, 2012). Many of the practices of the comprehension approach will remain in the listening classroom, yet one must be aware of its limitations. One of these limitations is the fact that it is teacher-centered, with the teacher setting the questions, passing judgement on the answers, and deciding which parts of the recording to replay (Field, 2008a). Such shortcomings indicate that the comprehension approach is not in line with CLT. Further, with its emphasis on "methods associated with testing rather than teaching, the comprehension approach tends to isolate learners" (Field, 2008a, p. 31). Listening is the most internalized of the four language skills, hence, is by its nature isolating. Yet, with a focus on the right answer, rather than on discussing what has been heard, listening teachers are increasing this isolating effect (Field, 2008a). This being the case, the atmosphere in a listening class resembles that of an exam rather than that of "a forum for communicative practice of the second language" (Field, 2008a). Further, the comprehension approach does not provide the learners with strategies to deal with listening outside the classroom. This could explain why some listeners achieve pretty high levels of success in classroom listening but would be unable to achieve the same success in listening events outside the classroom (Field, 2008a).

The basic assumption behind the comprehension approach is that simple exposure to the language would enable learners to advance, so it makes "no real provision for development" (Field, 2008a, p. 99). The major problem with this approach to listening is the focus it places on the product of listening, while neglecting the actual process (Field, 2008a). Thus, this approach does not serve the purpose of teaching L2 listening sufficiently. "With a focus on the product of listening, every activity becomes a test of the learners' listening ability" (Goh, 2008, p.191). This consequently leads to further anxiety on behalf of the L2 learners (Vandergrift \& Goh, 2009). For a listening class to be effective, it must recognize listening as "an active, strategic and constructive process" (Vandergrift \& Goh, 2009, p.402). Yet an emphasis on trying to understand the message leaves no room for the learners to step back and learn how the listening input is actually dealt with (Vandergrift \& Goh, 2012). Neither do listeners in the comprehension approach receive any guidance on how they can self-regulate 
and evaluate their efforts to improve their listening level (Vandergrift \& Goh, 2012). Goh (2005) says that "to help learners develop expertise in listening, some of these practices will have to change" (p. 77). She agrees that the three- stage lesson of pre-while- and post-listening is still helpful, but the emphasis in a listening lesson must expand to include knowledge about listening processes. This lack of focus on the actual process of listening in the comprehension approach is actually what has given rise to the metacognitive approach.

\subsection{The Metacognitive Approach}

Recent discussions on teaching listening comprehension have shifted the focus to the roles of strategy training and metacognitive knowledge in developing listening (Goh, 2008). Yet, evidence for the effectiveness of listening strategy training remains quite mixed (Lynch, 2002). The metacognitive approach is more comprehensive than strategy training as it tackles not only strategies, but it goes further to "the development of learners' metacognitive knowledge of themselves as L2 listeners and the mental and social processes of listening" (Goh \& Hu, 2014, p. 256). Research indicates that it is the use of metacognitive knowledge that enables proficient listeners to control comprehension processes (Vandergrift \& Goh, 2012). In fact, having a rich repertoire of metacognitive knowledge is characteristic of students with good listening abilities (Goh, 2005). In the area of listening development, interventions that were more successful focused largely on the development of metacognitive strategy (Macaro et al., 2007). Empirical evidence in the field also suggests the positive impact the metacognitive approach has on listening development (Goh \& $\mathrm{Hu}, 2014$ ).

At the heart of the metacognitive approach lies the concept of metacognition, which originated as a theoretical construct from the work of Flavell (1979). Simply defined, metacognition is "cognition about cognition" (Flavell, 2000, p. 16). Metacognitive knowledge, in particular, consists mainly of "knowledge or beliefs about what factors or variables act and interact in what ways to affect the course and outcome of cognitive enterprises" (Flavell, 1979, p.907). Flavell identified three major categories of metacognitive knowledge, which are person, task and strategy knowledge. In the light of L2 listening, Goh (2008) defines person knowledge as "the way individuals learn to listen and the factors that influence one's own listening," task knowledge as "the nature and demands of listening tasks," while strategy knowledge refers to "effective ways to learn or accomplish a listening task" (p.197).

A general consensus among researchers in the field is that metacognition enhances both thinking and comprehension (Vandergrift \& Goh, 2012). Metacognition can partly compensate for some of the limitations in students' learning, yet the role it plays in L2 listening has only been looked into recently (Goh \& Hu, 2014). Metacognition is in fact critical to the learning process, as it impacts the way learners plan, manage and direct their own learning (Goh \& $\mathrm{Hu}, 2014$ ). One significant virtue of metacognition is that it leads learners to being "active participants in their own performance rather than passive recipients of instruction and imposed experience" (Paris \& Winograd, 1990, p. 18). By promoting learners' awareness of their own thinking, teachers help in shifting the responsibility of monitoring learning to the learners themselves, which consequently leads to "positive 
self-perceptions, affect and motivation among students" (Paris \& Winograd, 1990, p. 15). Metacognition has an impact on the way learners approach tasks and on their beliefs in their own abilities. Hence, increasing students' metacognition about learning has a motivational as well as a cognitive consequence. The latter is manifested by enabling learners to tackle problems strategically, while the former is seen by students feeling "empowered to be successful" (Paris \& Winograd, 1990, p.43). The comprehension approach, as mentioned previously, leads to further anxiety on behalf of the learner due to its focus on the right answer. The metacognitive approach, however, tackles this issue, as it has shown to decrease language anxiety and increase confidence when approaching a listening task (Goh \& Taib, 2006). The following part will demonstrate how metacognitive instruction can be carried out in the L2 listening classroom, i.e. how to raise awareness to metacognitive knowledge in L2 listening classes.

\subsection{Participant (Subject) Characteristics}

\subsubsection{Metacognitive Instruction}

Metacognitive instruction is defined by Vandergrift and Goh (2012) as "pedagogical procedures that enable learners to increase awareness of the listening process by developing richer metacognitive knowledge about themselves as listeners, the nature and demands of listening, and strategies for listening" (p.97). In other words, metacognitive instruction refers to "teaching that explicitly elicits and develops learners' knowledge about the listening process" (Goh \& Taib, 2006, p. 222). Learners' awareness about listening cannot be observed directly, yet we can still have access to this type of knowledge through asking learners to tell us about it (Goh, 1997).

A variety of methods have been used to implement some form of metacognitive instruction in L2 listening lessons, including the use of checklists, guided listening diaries, group discussions and the use of questionnaires, such as the metacognitive awareness listening questionnaire (MALQ). All of these methods are considered indirect ways of developing L2 listening. They allow learners to "step back from real-time listening, examine their listening processes and develop their own thinking about what it takes to be an effective listener" (Vandergrift \& Goh, 2009, p. 402). Also, a pedagogical cycle suggested by Vandergrift, and applied in many studies on L2 listening instruction, improves both top-down and bottom-up dimensions of listening, as well as raising the learners' metacognitive awareness of processes which underlie successful L2 listening (Vandergrift \& Goh, 2009).

Goh (2008) proposed a metacognitive instruction framework which consists mainly of metacognitive knowledge and metacognitive strategies. Metacognitive strategies, when compared to cognitive ones, Goh (2005) says, "are less frequently used even by L1 listeners and should be developed to improve control" (p. 78). Goh (2008) explains that although research into metacognitive instruction in listening lessons is "still relatively new," the results of this research indicate that L2 learners show some level of metacognitive knowledge about the listening process, and about themselves as L2 listeners (p. 195). Metacognitive instruction influences students' listening performance by altering "the manner in which the learners approach the task of listening and learning to listen" (Goh, 2008, p.196). Given that listening 
is a hidden process that takes place in the listeners' heads, metacognitive activities allow learners to uncover these processes.

According to Goh (2005), having the appropriate task knowledge about listening enables learners to plan, monitor and evaluate their listening rather than approaching listening randomly. Strategy knowledge further enables the listeners to use the appropriate strategies to comprehend texts and to generally improve their listening abilities. Person knowledge helps learners attend to problems in general, particularly those they may experience on an individual basis. A brief review of previous studies in the field of L2 listening led Goh (2005) to conclude that metacognitive instruction helps learners become less anxious and more motivated. It also has a positive influence on the learners' listening ability. In fact, a number of studies in the field indicated a causal relationship between metacognitive instruction and statistically significant improvement in listening ability (Vandergrift \& Goh, 2012). These findings are particularly true for weak listeners, who have been found to benefit more from metacognitive instruction.

Metacognitive knowledge, Goh (2005) says, is one type of knowledge that is necessary to achieve listening expertise. However, one limitation of the metacognitive approach is that it tends to focus rather exclusively on the use of strategies and does not go further to help learners with other forms of learning to listen, either inside or outside the classroom (Goh, 2008). Another limitation that emerges from the results of studies reviewed in the area of metacognitive instruction is that it is less-skilled listeners who benefit more from metacognitive instruction. Hence, as Cross (2011) concluded, this form of instruction may not be equally helpful to all learners in a language classroom. This supports my argument that to achieve L2 listening expertise, metacognitive instruction alone is not sufficient. As mentioned previously, and as the definition of expertise illustrates, deliberate practice is what seems to distinguish experts from novice peers. The element of extended practice, in general, let alone deliberate practice, is mainly missing from Goh's definition of L2 listening expertise. In fact, Goh and $\mathrm{Hu}$ (2014) state that "there are even calls to abandon a strategy approach in preference for more listening practice” (p. 269). This is the very issue the deliberate practice approach addresses.

\subsection{The Deliberate Practice Approach}

Expertise used to be explained previously as "an orderly progression from novice to intermediate and to expert" (Ericsson, 2006b, p. 688). Yet, the most appropriate method to find out how and why people excel in a certain field is through studying individuals who have gained very high levels in their fields (Ericsson, 2002). While studying a number of masters in different areas of expertise, Ericsson (2002) happened to find that such masters stressed the roles played by motivation, concentration and willingness to exert the required effort in order to improve their performance. This led Ericsson and his fellow researchers to define a theory which determines the elements required for practice to be effective and thus would lead to expertise in a field. In the light of this theory, deliberate practice is considered to be the key requirement for the achievement of expert performance (Eysenck \& Keane, 2010). Results of research carried out in this area emphasize the importance of deliberate practice as opposed to 
non-deliberate practice for the attainment of high levels of expertise (Eysenck \& Keane, 2010). A lot of research conducted in the fields of music, sports and chess uncovered a rather "consistent relation between performance level and the quality and amount of deliberate practice" (Ericsson, 2002, p. 28). Thus, the significance of being engaged in specific, domain-related activities to achieve expertise is now well-established (Ericsson, 2002).

Ericsson et al. (1993) have put together a theoretical framework that explains expert performance as the ultimate result of engaging in extensive amounts of deliberate practice. The purpose of deliberate practice, in general, is to aid in improving a number of aspects of performance effectively, on the road to achieving expert performance. In an attempt to gain further insight into expert performance, Ericsson et al. (1993) asked a number of musicians to keep regular diaries about their current forms of practice. Their aim was to assess the length of time as well as regularity of the different kinds of activities this group of musicians engaged in, mainly those that represent deliberate practice. Ericsson and his fellow researchers also carried out a study that compared a group of young expert pianists with another group of amateur pianists. On the basis of data collected from this study, the researchers identified large differences between the two groups in regards to the histories of deliberate practice. Data collected from the diaries showed that the current quantity of practice was 10 times more for the experts than their amateur peers. Being motivated to improve performance, having well-defined tasks and being given feedback on their performance as well as having opportunities for repeated performance were all found to be major elements that led to steady improvement in performance. Such practice activities were in fact limited in time and evenly distributed across the whole week. Based on this research, Ericsson and his colleagues coined the term 'deliberate practice' to refer to "activities that have been specially designed to improve the current level of performance" (Ericsson et al., 1993, p.367). At the core of their framework lies the belief that "expert performance is the result of an extended process of skill acquisition mediated by large, but not excessive daily amounts of deliberate practice" (Ericsson et al., 1993, p. 389).

Ericsson (2006b) believes that being engaged in deliberate practice helps individuals focus on actively trying to move beyond their current levels of performance, which is quite different from the impact of mere experience. In fact, the element of concentration, which is required to be present when being engaged in deliberate practice, is what distinguishes this form of practice from other routine performance as well as playful engagement. Deliberate practice is different from enjoyable play in that it is an activity which should be highly structured aiming at improving performance (Ericsson et al., 1993). However, individuals who have reached expert levels in different fields conveyed that their ability to maintain their concentration that is a requirement of deliberate practice limited their hours of practice (Ericsson, 2002).

Deliberate practice is undoubtedly an effortful activity that generates no financial rewards. Therefore, the most cited requirement for ultimate learning and improvement of performance to happen is the individual's motivation to undertake the task and make the effort needed to improve their performance (Ericsson et al., 1993). Sustained motivation can be achieved through the presence of a tutor in order to monitor performance and assess improvement. A tutor is expected to set the task, provide the required amount of support and guidance and 


\section{Macrothink}

finally give sufficient feedback based on the individual's performance. The tutor does not necessarily have to be a teacher or coach, as it can also be computer-based (Bransford et al., 2000). Ericsson et al. (1993) elaborate on the necessity of feedback by saying that with the absence of sufficient feedback, "efficient learning is impossible and improvement only minimal even for highly motivated subjects" (p.367). Research shows that the effective duration of deliberate practice is estimated at around one hour per day. On the basis of the literature reviewed above, I summarize the major elements for deliberate practice in the Figure 1 below.

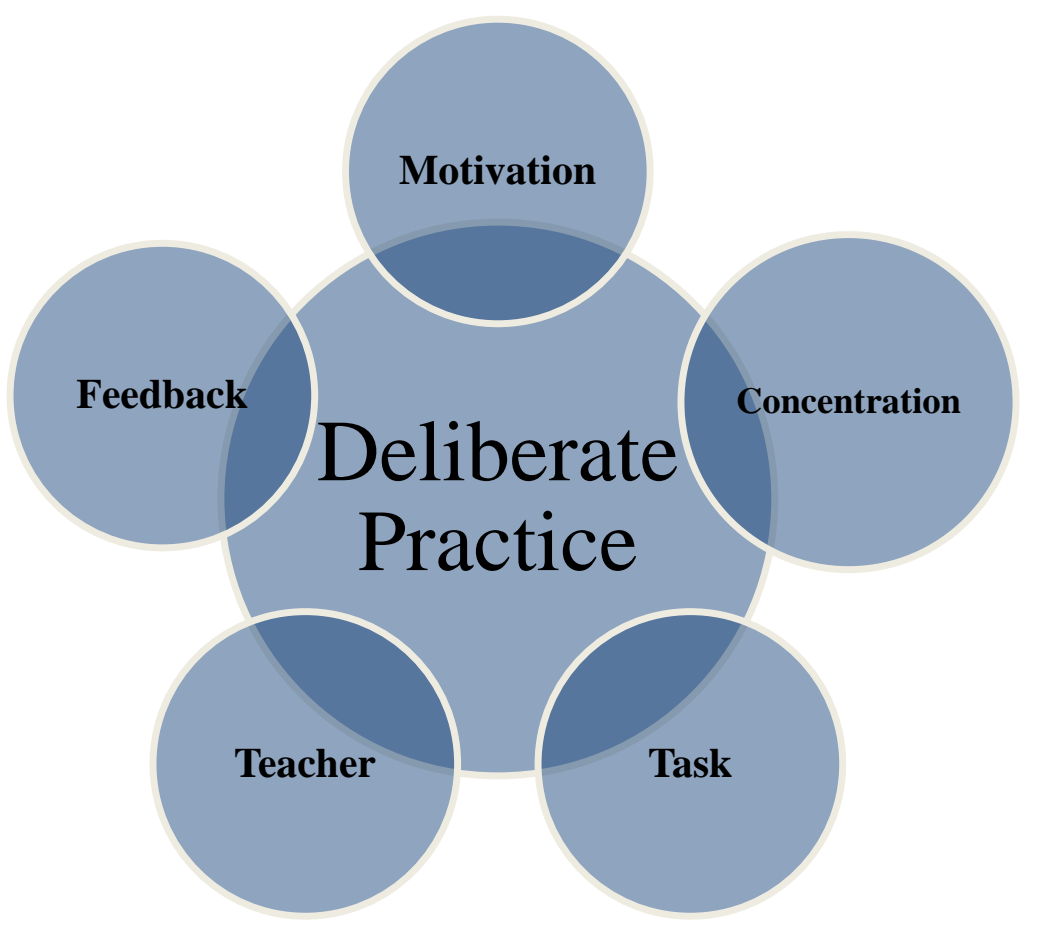

Figure 1. Elements of Deliberate Practice (Source: Original)

The skill acquisition theory best explains the reason why a lot of people are able to improve their level of performance within a few months and then reach an automatized stage, while experts are able to continue improving their levels of performance for years ahead (Ericsson, 2006b). When an individual starts engaging in learning a specific skill, he/she has to focus on the things they are doing as an attempt to minimize the rate of errors; this is what is meant by the cognitive stage, which is the first stage of the skill acquisition theory, as previously mentioned. When individuals gain more experience, they are capable of performing at satisfactory levels without the need for concentrating as hard as they had to in stage one. At this second stage, the individual's level of performance seems smoother, and errors become more infrequent. This stage is what is known as the associative stage. As the individuals gain more experience and have more training, their behavior becomes increasingly automated due to the loss of conscious control that they initially had, and thus their ability to make any intentional changes is also gone. When any skill reaches this third automated stage, one's 
level of performance gets to a rather fixed plateau, and no additional improvements can be seen (Ericsson, 2006b).

The performance of experts, on the other hand, keep on improving as a result of more experience that is combined with deliberate practice. Thus, the challenge for individuals who aim at achieving expert performance is avoiding the arrested development that is associated with automaticity as well as acquiring cognitive skills which help aid their continued learning and improvement (Ericsson, 2006b). For that to happen, they should seek out training opportunities that are above their current level of performance. This, Ericsson (2006b) explains, helps them "counteract automaticity by developing increasingly complex mental representations to attain higher levels of control of their performance" (p. 687). The principal challenge on the road to expertise is inducing changes that are stable and specific, allowing for performance to be gradually improved (Ericsson, 2006b).

Although I argue that deliberate practice is essential to the development of expertise, it is seldom sufficient on its own (Eysenck and Keane, 2010). Therefore, I attempted to integrate both metacognitive instruction and deliberate practice to gain benefits and overcome the weaknesses in each of the two approaches. Recently, researchers seem to generally accept that a relationship between metacognition and developing expertise does in fact exist (vanVelzen, 2012). This indicates that both deliberate practice and metacognitive knowledge are significant for the development of expertise. By integrating the two elements into L2 listening instruction, I aimed to challenge the current comprehension approach in which learners listen to the tape and give answers to questions without learning how to go about the listening input. Metacognitive instruction provides the L2 listeners with guidance on planning, monitoring and evaluation. It also helps the learners be in control of their learning, and hence increases motivation and confidence. Metacognitive instruction consequently leads students to have more control over their learning and be "more capable of regulating" it (Goh, 1998, p.47). Deliberate practice, on the other hand, motivates learners to move beyond their current level of performance by exerting the required mental effort.

Developing L2 listening expertise paves the way to language development in general. Field (2008a) explains that "listening competence has a critical effect upon learner motivation" (p.335). The development of listening expertise, Goh (2005) says, "is a gradual process" (p.78). Thus, in agreement with these two researchers, I argue for the presence of two phases in any L2 listening course in order to achieve an element of gradual movement. The first phase is concerned with metacognitive instruction whereas the second one is focused on deliberate practice in L2 listening.

\subsubsection{Deliberate Practice and Metacognitive Instruction}

The reality is that expertise relates not just to the amount of knowledge experts have, but also to the way they organize that knowledge and the ability to search efficiently through their knowledge and skills (vanVelzen, 2012). In fact, "the power of metacognitive control can be seen perhaps nowhere better than in the skill of experts" (Kellogg, 1995, p. 212). Hence, metacognition has been shown to develop as expertise increases (Shreve, 2006). By developing metacognitive knowledge, students are expected to be in control of their own 
learning, since this knowledge provides learners with a tool that helps them analyze new information, evaluate key aspects, and search for ways to improve (Kellogg, 1995). Therefore, metacognitive knowledge is regarded as "a general tool that can support the development of expertise" (Kellogg, 1995, p.366). Metacognitive training helps students understand the cognitive processes that are necessary during school learning and how these processes can support the development of expertise (vanVelzen, 2012). However, "metacognition is necessary, but not sufficient, for academic success" (Hartman, 2001, p.34).

The metacognitive instruction phase is in fact best conducted over a short period time, functioning as an introductory phase before moving onto deliberate practice. Paris and Winograd (1990) state that metacognition should not be viewed as the end goal for learning instruction. Rather, it is part of on-going thinking as well as problem solving and functions as a transitional stage to proficiency. The aim of any education, they say, is not to produce "reflective thinkers who are cautious and self-conscious about their own thinking" (p.22). That would undoubtedly immobilize learning rather than nourish it. Therefore, the goal of metacognitive instruction, Paris and Winogard believe, is to equip learners with the knowledge and confidence they need to manage their own learning and to give them the power to be curious and passionate enough in their learning journeys. This signals the necessity of not restricting the teaching of L2 listening to metacognitive instruction, but using it as a means to an end, rather than an end in itself. Including a short metacognitive instruction phase allows the less skilled learners to acquire new ways to aid them in coping with the listening input. This short phase would also reinforce the good practices more successful listeners already do, and by keeping it short, prevent this group of learners from responding negatively to instruction. Research indicates that successful learners "possess more metacognitive awareness and engage in more self-regulatory behaviour than low achieving students" (Hartman, 2001, p. 33).

Deliberate practice also involves self-reflection after the completion of practice; self-reflection being a key characteristic of metacognition (Baron \& Henry, 2010). Hence, deliberate practice is believed to "enhance[s] cognitive resources with respect to metacognition" (Baron \& Henry, 2010, p. 56, italics in original). These illustrations seem to indicate that the two entities of metacognition and expertise go hand-in-hand, with one increasing as the other develops. In fact, vanVelzen (2012) clarifies that the link between metacognitive knowledge and expertise relates to problem solving in that "it can help students become better problem solvers" (p. 366). Apart from the role the teacher plays by setting the task, facilitating repeated performance and providing feedback to the student, the remaining two vital components of deliberate practice, which are motivation and concentration, are closely related to metacognitive knowledge. Motivation and concentration are referred to in the literature on metacognition as self-management and directed attention respectively. These two are examples of planning strategies which fall under strategic knowledge. This suggests that deliberate practice will most likely take place by developing strategic knowledge with the presence of the teacher as a coach.

Deliberate practice is a learner-centered approach, since it is in the hands of the learners themselves to aim at improving their current level of performance and exert the required 


\section{Al Macrothink}

effort, motivation and concentration. The diligence, concentration and effort required for deliberate practice yields many significant cognitive benefits. The teacher under this approach acts merely as a coach, providing suitable tasks, monitoring performance, giving feedback and allowing for repeated performance.

\subsubsection{Deliberate Practice in the L2 Listening Classroom}

Despite the fact that the term deliberate practice has been mentioned in the area of SLA (Ortega, 2009), few if any attempts have been made to apply this concept to the language classroom. One reason may be that researchers are uncertain about how this may differ from drills and practice methods of the audio-lingual era. In many language classrooms, however, listening remains "a mysterious 'black box', for which the best approach seems to be simply "more practice"' (Rost, 2001, p. 13). The metacognitive approach put forward by Vandergrift and Goh (2012) does not appear to be sufficient for producing proficient L2 listeners. In fact Sternberg (2001) indicates that metacognition represents "part of the abilities that lead to student expertise, but only as part" (p. 247).

The approach proposed in this article is one of learning through practice rather than learning through instruction and is perforce learner-centred. The role of the teacher in this approach is similar to that of a coach in sports practice. The teacher sets an achievable, yet challenging task, provides feedback, opportunities for repetition, and reinforces the significance of concentration and motivation at the start of each session. The application of deliberate practice in an L2 listening class, though it is crucial to listening development, may not be very apparent to the outside observer because many of the procedures in class are the same as they would be in any conventional listening class. The difference largely relates to the listeners' internal psychological processes.

Based on what has been discussed above, I describe what a deliberate practice-based L2 listening course looks like, as summarized in Figure 2 below. 


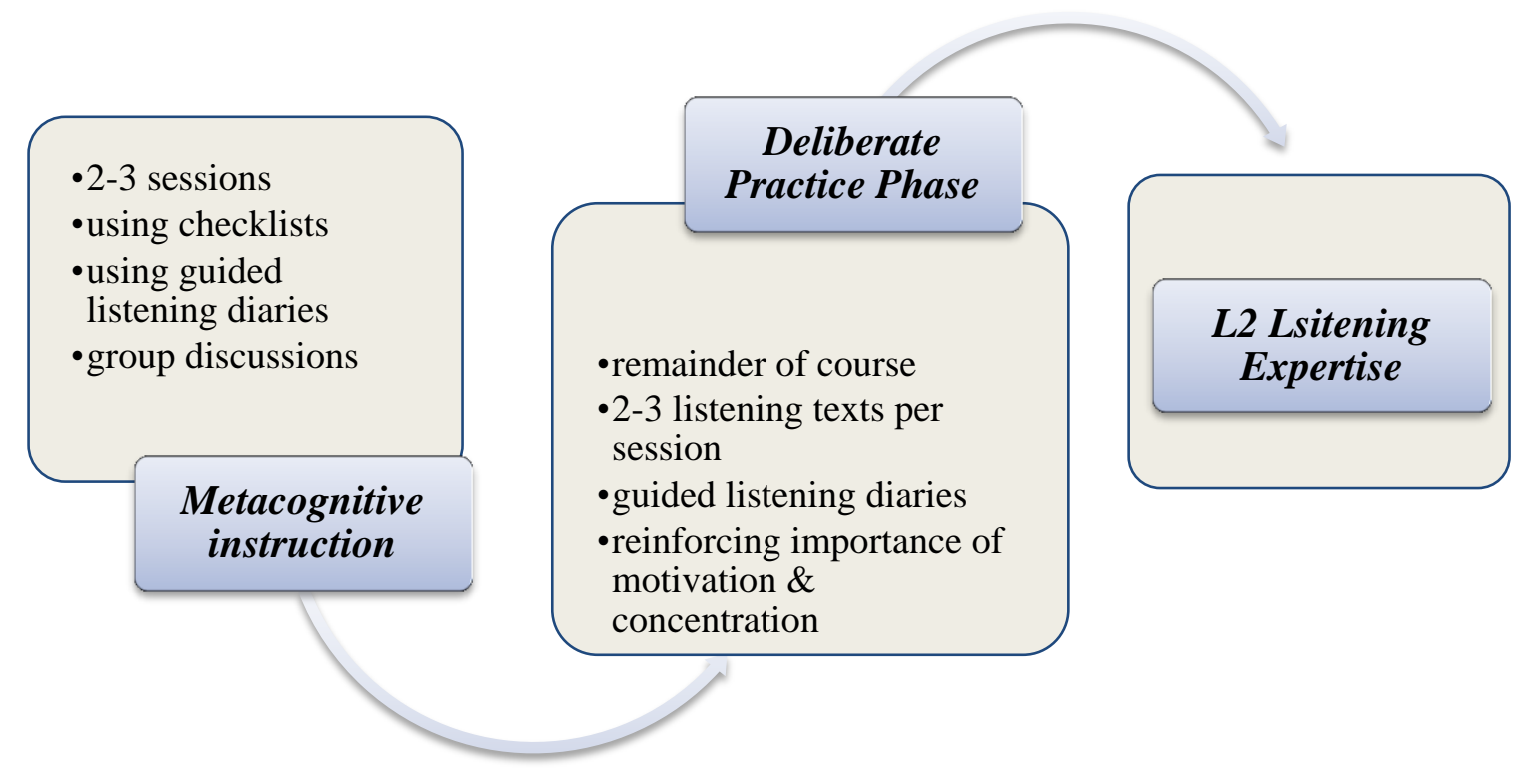

Figure 2. Deliberate Practice Based L2 Listening Course

\section{Conclusion}

To conclude, Ortega (2009) states that deliberate practice "is a concept that is very much relevant to L2 learning but has not made it into SLA yet!" (p. 108). It has been more than twenty years now since the term deliberate practice was first coined by Ericsson et al. (1993), but it has still not made it into the language classroom. Ericsson (2006b) explains that the significance of practice should not be under-estimated "until most individuals recognize that sustained training and effort is a prerequisite for reaching expert levels of performance, they will continue to misattribute lesser achievement to the lack of natural gifts, and will thus fail to reach their own potential" (p. 701).

The principles established by research on expert performance and deliberate practice are applicable to a wide range of fields, including music, chess, sports and medicine. Hence, there is ample evidence to suggest that they may also be applicable to SLA. Deliberate practice is assumed to "reduce the central cognitive load" (Anderson, 2010, p. 303). The cognitive load is rather high in the case of L2 listening, hence, applying deliberate practice is expected to lead to a positive effect on L2 learners' listening level. In deliberate practice, Anderson says, "the learners are motivated to learn, not just perform" (Anderson, 2010), which is a major component missing in the comprehension approach.

The approach to L2 listening instruction proposed in this article is definitely not the solution for all language learners, especially those who lack the required motivation. Yet, it seems promising for second/foreign language major students as well as those doing a language 
course who are expected to be motivated enough to undertake the pains of deliberate practice. The discussion above suggests that deliberate practice is a concept whose time has come in the field of language learning. With the wealth of resources available nowadays, deliberate practice can be easily facilitated by language teachers. Goh (2005) says that there is "a modest but growing body of work that examines the features of listening expertise" (p.79). However, most of the studies to date have been descriptive in nature, as they merely record the characteristics of listening expertise of learners from various learning and cultural contexts (Goh, 2005). The present article differs from previous studies in the field in that it aimed at finding a way to develop listening expertise, rather than describing what distinguishes L2 expert listeners from their novice peers. It is just one step in the journey towards the effective application of deliberate practice in the L2 classroom.

\section{References}

Anderson, J. (2010). Cognitive psychology and its implications $\left(7^{\text {th }}\right.$ ed.). New York: Worth Publishers.

Baron, R., \& Henry, R. (2010). How entrepreneurs acquire the capacity to excel: insights from research on expert performance. Strategic Entrepreneurship Journal, 4, 49-65. https://doi.org/10.1002/sej.82

Bereiter, C., \& Scardamalia, M. (1993). Surpassing ourselves : an inquiry into the nature and implications of expertise. Chicago Open Court.

Bransford, J., Brown, A., \& Cocking, R. (2000). How People Learn: brain, mind, experience, and school. Washington, D. C.: National Academy Press.

Cross, J. (2011). Metacognitive instruction for helping less skilled listeners. ELT Journal, 65(4), 408-416. https://doi.org/10.1093/elt/ccq073

Dekeyser, R. (2007a). Introduction: Situating the concept of practice. In: Dekeyser, R. (ed.) Practice in a Second Language: Perspectives from Applied Linguistics and Cognitive Psychology. Cambridge: Cambridge University Press.

Dekeyser, R. (2007b). Skill acquisition theory. In: Vanpatten, B. \& Williams, J. (eds.) Theories in second language acquisition: an introduction. New Jersey: Lawrence Erlbaum Associates, Inc.

Ericsson, K. A. (2002). Attaining excellence through deliberate practice: insights from the study of expert performance. In: Ferrari, M. (ed.) The Pursuit of Excellence Through Education. Mahwah: Lawrence Erlbaum Associates.

Ericsson, K. (2006a). An introduction to Cambridge handbook of expertise and expert performance: its development, organization and content. In: Ericsson, K., Charness, N., Feltovich, P. \& Hoffman, R. (eds.) The Cambridge handbook of expertise and expert performance. Cambridge: Cambridge University Press.

Ericsson, K. (2006b). The influence of experience and deliberate practice on the development of superior expert performance. In: Ericsson, K., Charness, N., Feltovich, P. \& Hoffman, 
R. (eds.) The Cambridge handbook of expertise and expert performance. Cambridge: Cambridge University Press.

Ericsson, K., Krampe, R., \& Tesch-Römer, C. (1993). The role of deliberate practice in the acquisition of expert performance. Psychological Review, 100, 363-406. https://doi.org/10.1037/0033-295X.100.3.363

Eysenck, M., \& Keane, M. (2010). Cognitive psychology: a student's handbook. Hove: Psychology Press.

Field, J. (2002). The changing face of listening. In: Richards, J. \& Renandya, W. (eds.) Methodology in language teaching: an anthology of current practice. Cambridge: Cambridge University Press.

Field, J. (2008a). Listening in the language classroom. Cambridge: Cambridge University Press.

Field, J. (2008b). Emergent and divergent: A view of second language listening research. System, 36, 2-9. https://doi.10.1016/j.system.2008.01.001

Feyten, C. M. (1991). The Power of Listening Ability: An Overlooked Dimension in Language Acquisition. The Modern Language Journal, 75(2), 173-180. https://doi.org/10.2307/328825

Flavell, J. (1979). Metacognition and cognitive monitoring: a new area of cognitive-developmental inquiry. American Psychologist, 34(10), 906-911. https://doi.org/10.1037/0003-066X.34.10.906

Flavell, J. (2000). Development of children's knowledge about the mental world. International Journal of Behavioral Development, 24(1), 15-23. https://doi.org/10.1080/016502500383421

Goh, C. (1997). Metacognitive awareness and second language listeners. ELT Journal, 51(4), 361-369. https://doi.org/10.1093/elt/51.4.361

Goh, C. (1998). Strategic Processing and Metacognition in Second Language Listening: Examining Comprehension Strategies and Tactics, Metacognitive Knowledge and Listening Ability. Doctor of Philosophy, Lancaster University. https://ethos.bl.uk/OrderDetails.do?uin=uk.bl.ethos.265817

Goh, C. (2005). Second language listening expertise. In: Johnson, K. (ed.) Expertise in second language learning and teaching. New York: Palgrave Macmillan. https://doi.10.1057/9780230523470_4

Goh, C. (2008). Metacognitive instruction for second language listening development: theory,

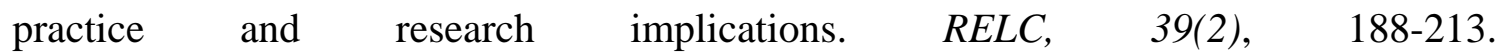
https://doi.org/10.1177/0033688208092184

Goh, C., \& Hu, G. (2014). Exploring the relationship between metacognitive awareness and listening performance with questionnaire data. Language Awareness, 23(3), 255-274. 
https://doi.org/10.1080/09658416.2013.769558

Goh, C., \& Taib, Y. (2006). Metacognitive instruction in listening for young learners. ELT Journal, 60(3), 222-232. https://doi.org/10.1093/elt/ccl002

Hartman, H. (2001). Developing Students' Metacognitive Knowledge and Strategies. In: Hartman, H. (ed.) Metacognition in Learning and Instruction: Theory, Research, and Practice. Dordrecht, The Netherlands: Kluwer Academic Publishers. https://doi.org/10.1007/978-94-017-2243-8_3

Kellogg, R. T. (1995). Cognitive Psychology. Thousand Oaks, CA: Sage Publications.

Lynch, T. (2002). Listening: questions of level. In: Kaplan, R. (ed.) The Oxford handbook of applied linguistics. Oxford: Oxford University Press.

Lynch, T. (2006). Academic listening: marrying top and bottom. In: Uso-Juan, E. \& Martinez-Flor, A. (eds.) Current trends in the development and teaching of the four language skills. Berlin: Mouton de Gruyter. https://doi.org/10.1515/9783110197778.2.91

Macaro, E., Graham, S., \& Vanderplank, R. (2007). A review of listening strategies: focus on sources of knowledge and on success. In: Cohen, A. \& Macaro, E. (eds.) Language learner strategies. Oxford: Oxford University Press.

Mendelsohn, D. (2006). Learning how to listen using learning strategies. In: Uso-Juan, E. \& Martinez-Flor, A. (eds.) Current trends in the development and teaching of the four language skills. Berlin: Mouton de Gruyter. https://doi.org/10.1515/9783110197778.2.75

Nunan, D. (2002). Listening in language learning. In: Richards, J. \& Renandya, W. (eds.) Methodology in language teaching: an anthology of current practice. Cambridge: Cambridge University Press.

Ortega, L. (2009). Understanding Second Language Acquisition. London: Hodder Education.

Paris, S., \& Winograd, P. (1990). How metacognition can promote academic learning and instruction. In: Jones, B. \& Idol, L. (eds.) Dimensions of Thinking and Cognitive Instruction. New Jersey: Lawrence Erlbaum Associates.

Rost, M. (2001). Listening. In: Carter, R. \& Nunan, D. (eds.) The Cambridge guide to teaching English to speakers of other languages. Cambridge: Cambridge University Press.

Rost, M. (2006). Areas of research that influence L2 listening instruction. In: Uso-Juan, E. \& Martinez-Flor, A. (eds.) Current trends in the development and teaching of the four language skills. Berlin: Mouton de Gruyter. https://doi.org/10.1515/9783110197778.2.47

Segalowitz, N. (2003). Automaticity and second languages. In: Doughty, C. \& Long, M. (eds.) The handbook of second language acquisition. Oxford: Blackwell Publishing. 
Shreve, G. (2006). The deliberate practice: translation and expertise. Journal of Translation Studies, 9, 27-42.

Sternberg, R. (2001). Metacognition, abilities, and developing expertise: what makes an expert student? In: Hartman, H. (ed.) Metacognition in Learning and Instruction: Theory, Research and Practice. Dordrecht, The Netherlands: Kluwer Academic Publishers. https://doi.org/10.1007/978-94-017-2243-8_12

Vandergrift, L. (1997). The comprehension strategies of second language (French) listeners: a descriptive study. Foreign Language Annals, 30(3), 387-409. https://doi.org/10.1111/j.1944-9720.1997.tb02362.x

Vandergrift, L. (2004). Listening to learn or learning to listen? Annual Review of Applied Linguistics, 24, 3-25. https://doi:10.1017/S0267190504000017

Vandergrift, L. (2007). Recent developments in second and foreign language listening comprehension research. Language Teaching, 40(3), 191-210. https://doi:10.1017/S0261444807004338

Vandergrift, L., \& Goh, C. (2009). Teaching and testing listening comprehension. In: Long, M. \& Doughty, C. (eds.) The Handbook of Language Teaching. Chichester: Wiley-Blackwell.

Vandergrift, L., \& Goh. C. (2011). Teaching and learning second language listening: Metacognition in action. Oxon: Routledge. https://doi.org/10.4324/9780203843376

VanVelzen, J. H. (2012). Teaching metacognitive knowledge and developing expertise. Teachers and Teaching: Theory and Practice, 18(3), 365-380. https://doi.org/10.1080/13540602.2012.629843

\section{Copyright Disclaimer}

Copyright for this article is retained by the author(s), with first publication rights granted to the journal.

This is an open-access article distributed under the terms and conditions of the Creative Commons Attribution license (http://creativecommons.org/licenses/by/4.0/). 